Making sense of whistle-blowing's antecedents: Learning from research on identity and ethics programs

By: Abhijeet K. Vadera, Rugh V. Aguilera, and Brianna B. Caza

Vadera, A., Aguilera, R., Caza, B, B (2009). Making sense of whistle-blowing's antecedents: Learning from research on identity and ethics programs. Business Ethics Quarterly, 19, 4: 553586.

This article has been published in a revised form in Business Ethics Quarterly https://doi.org/10.5840/beq200919432. This version is free to view and download for private research and study only. Not for re-distribution or re-use. (C) 2009 Society for Business Ethics.

\begin{abstract}
:
Despite a significant increase in whistle-blowing practices in work organizations, we know little about what differentiates whistle-blowers from those who observe a wrongdoing but chose not to report it. In this review article, we first highlight the arenas in which research on whistle-blowing has produced inconsistent results and those in which the findings have been consistent. Second, we propose that the adoption of an identity approach will help clarify the inconsistent findings and extend prior work on individual-level motives behind whistle-blowing. Third, we argue that the integration of the whistle-blowing research with that on ethics programs will aid in systematically expanding our understanding of the situational antecedents of whistle-blowing. We conclude our review by discussing new theoretical and methodological arenas of research in the domain of whistle-blowing.
\end{abstract}

Keywords: whistle-blowers | work organizations | ethics | identity

Article:

U.S. organizations lose five percent of their annual revenues, equivalent to $\$ 652$ billion, to fraud (Association of Certified Fraud Examiners, 2006). This huge loss suggests that organizations and their various stakeholders need to monitor better those engaging in white-collar crime and other unethical practices in organizations. Miceli and Near (2005) argued that the most effective stakeholders for reducing the occurrence of unethical behaviors in organizations were the employees of the organizations. For instance, in a study conducted by the Association of Certified Fraud Examiners (2006), 'tips,' mainly from employees, were found to be the most common means by which fraud was detected. However, another survey on workplace ethics (Hudson Employment Index, 2005) showed that of the almost one third (31 percent) of U.S. employees witnessing co-workers engaging in ethical misconduct, only half ( 52 percent) reported it to an authority. Non-reporting of unethical practices by those observing them may influence the occurrence of crimes in the modem organization. In fact, from 1996 to 2005, the federal government, through the help of whistle-blowers, recovered $\$ 9.3$ billion in fraudulent Medicare claims, according to data from the Department of Justice (Hernandez, 2008). Given these striking reporting rates and figures, it is clear that we need to understand better the 
individual and situational antecedents of whistleblowing so that organizational members can be encouraged to adopt this effective mode of "societal control mechanism over organizational misdeeds" (Miceli \& Near, 2005: 98).

Whistle-blowing is defined as "the disclosure by organization members (former or current) of illegal, immoral, or illegitimate practices under the control of their employers, to persons or organizations that may be able to effect action" (Near \& Miceli, 1985: 4). Our review of the whistle-blowing literature indicates that research in this field can be largely divided into studies examining the predictors of the observation of wrongdoing (e.g., Miceli \& Near, 1992), the antecedents of the actual act of whistle-blowing (e.g., Brewer \& Selden, 1998; Dworkin \& Baucus, 1998; Miceli \& Near, 1988), the process of whistle-blowing (e.g., Dozier \& Miceli, 1985; Near \& Miceli, 1985), and the factors that predict retaliation against whistle-blowers (e.g., Miceli \& Near, 2002; Rothschild \& Miethe, 1999). Figure 1 offers an illustration of the extant research of whistle-blowing broadly defined.

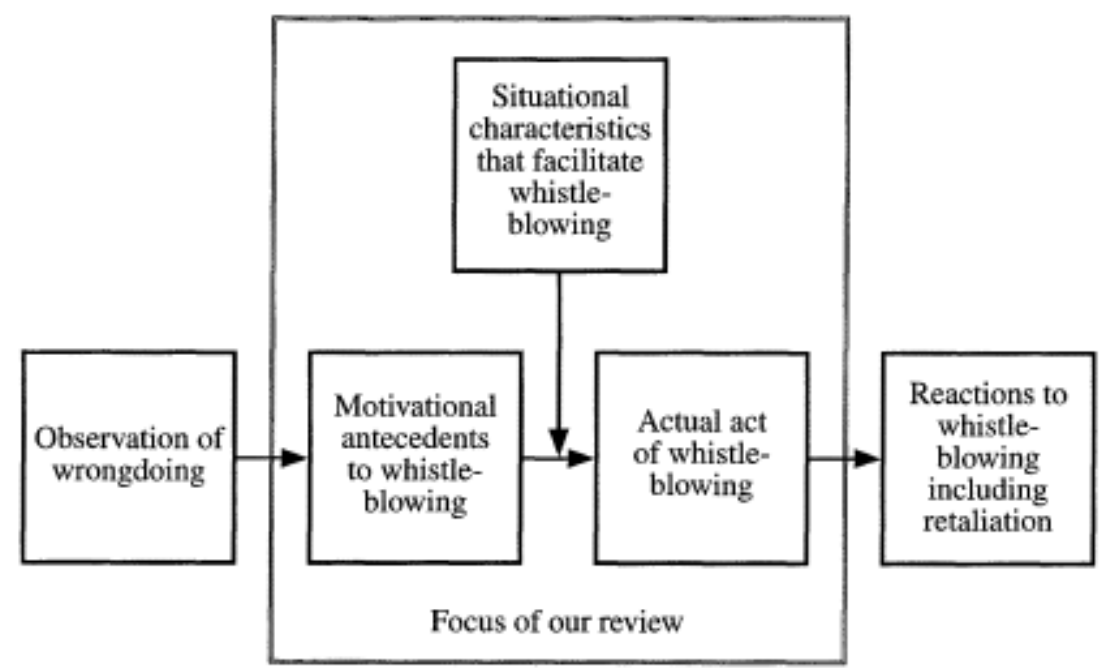

Figure 1. Extant Literature of Whistle-Blowing

In this article, we focus on the individual and situational antecedents of the decision to blow the whistle, in order to uncover both the consistent and inconsistent findings in whistle-blowing research, and to identify new and fruitful future areas of research. Toward this goal, we searched the mainstream organizational and ethics journals for empirical articles on whistle-blowing. ${ }^{1} \mathrm{We}$ also included book chapters and unpublished dissertations to gamer a more complete and updated understanding of the factors that influence an individual's decision to blow the whistle. Given the size of the extant literature on this topic, we have limited our review mainly to those studies which explicitly focus on whistle-blowing. Table 1 (see Appendix) provides a summary

\footnotetext{
${ }^{1}$ Specifically, we searched articles from the Academy of Management Journal (1984-2008), Business Ethics Quarterly (1991-2008), Employees Responsibilities and Rights Journal (1998-2008), Group \& Organization Management (1992-2008), Human Relations ( 1965-2008), Journal of Business Communication (1963- 2009), Journal of Public Administration Research and Theory (1991-2009), Journal of Business Ethics (1982- 2009), Personnel Psychology (1965-2008), and Work and Occupations (1974-2008). For unpublished dissertations, we used the ProQuest engine to search for relevant dissertations on whistle-blowing.
} 
of all the key studies on the antecedents of whistle-blowing highlighting their key concepts, variables, predictions and findings, and method and sample used.

This article is organized as follows. We first review work on the individual antecedents of whistle-blowing, with the aim of highlighting the consistent and inconsistent findings in the literature. Building on this body of research, we consider how adopting an identity-based approach to whistle-blowing is compatible with what we know about the consistent findings in the literature, and may further help explain its inconsistent findings, as well as provide new possible avenues for research. Next, we review research on the situational antecedents of whistle-blowing. Compared to the individual antecedents of whistle-blowing, we find more consistency in this sub-literature. We discuss these results and propose that by integrating research on whistle-blowing with that on ethics programs in organizations, we may be able to comprehend better the contextual factors affecting whistle-blowing. Table 2 summarizes the various individual and situational antecedents of whistle-blowing. We conclude our review with a discussion of the methodological issues associated with the extant work on whistle-blowing and suggestions for fruitful avenues of future research.

Table 2. Individual Antecedents of Whistle-Blowing

\begin{tabular}{|l|l|}
\hline Consistent Factors & Inconsistent Factors \\
\hline Views Whistle-Blowing as Role Responsibility & Gender \\
Others & Age \\
$\bullet \quad$ Job Performance & Tenure \\
$\bullet \quad$ Ottachment \\
$\bullet \quad$ Job Satisfaction \\
$\bullet \quad$ Pay Level & $\bullet \quad$ Jab Satisfaction \\
$\bullet \quad$ Education & $\bullet$ Organizational Commitment \\
\hline$\quad$ Values Whistle-Blowing & Personal Morality \\
\hline
\end{tabular}

Situational Antecedents of Whistle-Blowing*

\begin{tabular}{|c|c|}
\hline Characteristics of Job/Organization & Characteristics of the Wrongdoing \\
\hline $\begin{array}{l}\text { Perceived Support } \\
\text { Organizational Justice } \\
\text { Organizational Climate/Culture } \\
\text { Organizational Performance } \\
\text { Organizational Resources } \\
\text { Private versus Public Organizations }\end{array}$ & $\begin{array}{l}\text { Type of Wrongdoing } \\
\text { Severity of Wrongdoing }\end{array}$ \\
\hline
\end{tabular}

* Since situational factors are more consistently associated to whistle-blowing, we present these factors as those relating to the job/organization and to the wrongdoing.

\section{INDIVIDUAL ANTECEDENTS OF WHISTLE-BLOWING}

A variety of individual-level factors are associated with the decision to blow the whistle. These factors include demographic characteristics such as age, gender and level of education, as well as personality variables such as locus of control, personal morality and one's attachment to the organization (Miceli \& Near, 1992). Although existing research on the individual differences between whistle-blowers and inactive observers has been informative, several findings remain inconsistent. 
As shown in Table 2, factors such as perceiving whistle-blowing as role responsibility, job performance, organizational position, and pay level have produced relatively consistent findings. In contrast, research on gender, age, tenure and personal morality as predictors of whistleblowing has yielded mixed results (Mesmer-Magnus \& Viswesvaran, 2005; Near \& Miceli, 1996). We review the consistent factors, followed by the inconsistent factors, in detail below.

\section{Consistent Factors}

\section{Role Responsibility}

Findings regarding formal and informal role responsibility and whistle-blowing are quite consistent, in that, observers of wrongdoing who view whistle-blowing as integral to their role in the workplace are more likely to blow the whistle. Miceli and Near (2002) analyzed (a) the 1980 U.S. Merit Systems Protection Board archival data, (b) data from questionnaires created and mailed by the Research Foundation of the Institute of Internal Auditors (IIA), and ( c) data from 1952 female respondents who had experienced sexual harassment working in the executive branch of the federal government. They found that observers were more likely to blow the whistle and to believe that their whistle-blowing was more effective when whistle-blowing was perceived to be a part of their role descriptions. Trevino and colleagues (Trevino \& Victor, 1992; Victor, Trevino, \& Shapiro, 1993), in their studies on peer reporting, also demonstrated that both the inclination to report a peer and the actual act of peer reporting, were positively associated with role responsibility as perceived by the whistle-blower. Lastly, Ellis and Arieli (1999), in their study involving Israeli Defense Forces ground forces, and Park and Blenkinsopp (2009), in their analyses of 296 responses from South Korean police officers, revealed that subjective norms about whistle-blowing-an individual's beliefs about whether significant others think that he or she should engage in the behavior-were positively related to internal and external whistleblowing.

\section{Other Factors}

Although results vary slightly across studies, whistle-blowers (as compared to inactive observers) tend to have good job performance, to be more highly educated, and to hold higherlevel or supervisory positions (see Mesmer-Magnus \& Viswesvaran, 2005). For example, Brewer and Selden (1998) showed that federal employees who engaged in whistle-blowing were more likely to be high performers in their organizations. Similarly, Miceli and Near (1984), after examining the 1980 U.S. Merit Systems Protection Board archival data, concluded that whistleblowing was positively related to individual performance. Additionally, they inferred that whistle-blowers tended to have higher education, pay levels and organizational positions than inactive observers. A few years later, Miceli and Near (1988) analyzed the 1984 U.S. Merit Systems Protection Board archival data to again uncover that whistle-blowing was associated with professional status. However, other studies have found no association of individual performance, education and organizational position to whistle-blowing (e.g., Goldman, 2001; Keenan, 2000; Miceli \& Near, 2002; Rothschild \& Miethe, 1999; Sims \& Keenan, 1998).

Inconsistent Factors 


\section{Gender}

The findings regarding gender and whistle-blowing are inconsistent. Some studies show that whistle-blowing is positively related to being male (Miceli \& Near, 1988); others report a positive association between whistle-blowing and being female (Mesmer-Magnus \& Viswesvaran, 2005); whereas still others find no relationship between gender and whistleblowing. Moreover, the theoretical arguments related to the role of gender on whistle-blowing have also been mixed. One stream of research (e.g., Rothschild \& Miethe, 1999) contends that women are likely to report questionable or illegal acts more frequently than men because women, on average, feel a greater public responsibility to speak against wrongdoing. The opposing view (see Miceli \& Near, 1984) is that to the extent that reporting questionable or illegal behavior is considered risky, men are more likely than women to report these acts since women tend to conform to a majority opinion more than men, and the majority opinion may be to not report.

Miceli and Near (1988), in their analyses of the 1984 U.S. Merit Systems Protection Board archival data, showed that men were more likely to blow the whistle. In contrast, Seifert (2006), in her dissertation examining the relationship between organizational justice and perceived likelihood of whistle-blowing, uncovered that being female was positively associated with perceived likelihood of whistleblowing. In their study on external whistle-blowing, Sims and Keenan (1998) also demonstrated that whistle-blowing was negatively related to being male (i.e., positively associated with being female). However, other studies by Dworkin and Baucus (1998), Goldman (2001), Lee, Heilmann, and Near (2004), and Rothschild and Miethe (1999) found no relationship between gender and whistle-blowing (also see Zhang, Chiu, \& Wei, 2009).

Age

Existing research has reported positive, negative, and absent associations between whistleblowing and age. Most of the arguments relating age and whistle-blowing are based on power theories. Researchers have argued that "more powerful employees who observe wrongdoing have less to fear from their organization than do less powerful employees, and are therefore more likely to blow the whistle" (Lee et al., 2004: 304), and age is one such "power variable" (see Miceli \& Near, 1988). On one hand, Goldman (2001) integrated the social processing theory with organizational justice theories to explore the conditions under which employees would file claims for discrimination, and found that older workers were more likely to decide to file claims for discrimination. Also, Stansbury and Victor (2009) developed a life-course perspective of whistle-blowing and demonstrated that young (and short-tenured) employees perceived less informal prosocial control and that informal prosocial control boosted whistle-blowing. On the other hand, although not the central focus of their research, Zhang and colleagues (Zhang et al., 2009) discovered that age was negatively related to internal whistle-blowing in China. Yet there are also studies which have found no relationship between age and whistle-blowing. These include Chiu's (2003) inquiry with Chinese professionals and managers, Dworkin and Baucus's (1998) research on internal versus external whistle-blowing, and Keenan (2000)'s article on whistle-blowing on less serious frauds (also see Lee et al., 2004; Sims \& Keenan, 1998).

\section{Tenure}


A systematic review of studies examining the association between tenure and whistle-blowing indicates that extant research is mostly concerned with the relationship between tenure and external versus internal whistle-blowing. Overall, tenure is found to be negatively related to external whistle-blowing and positively associated with internal whistle-blowing. Support for the negative relationship between tenure and external whistle-blowing stems from the argument that newcomers generally tend to be less familiar with appropriate channels for internal reporting. They may also identify less with the formal and informal goals and the culture of the newly joined organization. Therefore, they may rely more on external channels because they may perceive themselves to be organizationally powerless (Lee et al., 2004) or to have fewer idiosyncratic credits-the credits earned through the demonstration of competency in conforming to organizational norms and in helping achieve organizational goals (Hollander, 1958). In a related vein, newcomers may also have less personal investment in the organization and may be less concerned with stopping the wrongdoing using internal channels (Dworkin \& Baucus, 1998). Therefore, it is argued that newcomers are more likely to blow the whistle externally.

In effect, Dworkin and Baucus (1998), in their analyses using sixty-three legal cases involving wrongful firings in violation of a public policy, found that tenure was negatively correlated with external whistle-blowing. Miceli and Near (1988), in their study using the U.S. Merit Systems Protection Board 1981 survey, also showed that (internal) whistle-blowing was more likely to occur when observers of wrongdoing had more positive reactions to their work and/or had longer tenures. Most of the reporting in this case involved internal whistle-blowing with over 78 percent of all employees reporting a questionable activity to their immediate supervisors and approximately 32 percent reporting it to both, their supervisor and others above their supervisors in their organizations (U.S. Merit Systems Protection Board, 1984). However, other research analyzing internal and external whistle-blowing has found no significant relationship between tenure and whistle-blowing (e.g., Keenan, 2000; Rothwell \& Baldwin, 2007; Sims \& Keenan, 1998; Singer, Mitchell, \& Turner, 1998; Zhang et al., 2009).

\section{Attachment}

Research on the relationship between an employee's attachment to the organization - in terms of job satisfaction, pay satisfaction, job commitment and organizational commitment - and his/her likelihood to blow the whistle offers inconclusive findings (Brewer \& Selden, 1998; Near \& Miceli, 1996; Victor et al., 1993). The argument here is that loyalty or one's relationship with the organization is the main mechanism through which these attachment characteristics are associated with whistle-blowing. However, this prediction is not as straight forward as one would like. For example, whistle-blowers have been argued to be more loyal to the organization than inactive observers because they help the organization learn about the whistle-blowing event before the public does. Yet, whistle-blowers have been claimed to be disloyal if they use external agencies to report wrongdoings because this is likely to harm the organization. And finally, whistle-blowers have also been perceived as being loyal to the public but disloyal to the organization because they act in the interest of the public and not in a "self-interested ploy of stonewalling on behalf of the organization" (Near \& Miceli, 1996: 513 ). In sum, the prediction for the attachment's relationship to whistle-blowing can take different directions depending on how one interprets loyalty. 
Brewer and Selden (1998) analyzed data from 1992 Merit Principles survey conducted by U.S. Merit System Protection Board database and concluded that federal whistle-blowers were motivated by concern for public interest and reported high levels of job security, job achievement, job commitment, and job satisfaction. However, Somers and Casal (1994) provided evidence for a more complex relationship between commitment and whistle-blowing. They collected data from 613 management accountants who were members of the National Association of Accountants (NAA). Their analyses showed that the relationship between commitment and intent to report wrongdoing had the form of an inverted $U$, indicating that moderate levels of commitment were most likely to result in whistle-blowing. Lastly, Sims and Keenan (1998)'s study involving college students uncovered that external whistle-blowing was not significantly predicted by satisfaction or commitment.

\section{Personal Morality}

Research examining the link between whistle-blowing and morality (in terms of personal ideal values, i.e., values associated with viewing whistle-blowing as a moral obligation, moral perceptions regarding the seriousness of frauds, etc.) also found mixed support (e.g., Chiu, 2003; Keenan, 2000; Sims \& Keenan, 1999). For example, Keenan (2000) offered evidence for a positive relationship between moral perceptions of managers at all levels and the likelihood of blowing the whistle on less serious fraud. However, when testing this relationship for middlelevel managers, he uncovered the opposite relationship, i.e., moral perceptions were negatively associated with whistle-blowing on less serious frauds. In another study, Sims and Keenan (1998) administered a questionnaire on a convenience sample of 248 adult students enrolled in a college level undergraduate and/or graduate business class. They discovered that students with personal ideal values favorable toward whistleblowing were more likely to engage in external whistle-blowing. Similarly, Chiu (2003) posited and found a positive relationship between the judgment that whistleblowing was ethical and whistle-blowing intention.

The above section reviewed past research involving the individual antecedents of whistleblowing. Our review demonstrates that studies investigating factors such as education, organizational position, and viewing whistle-blowing as a role responsibility have yielded consistent findings, whereas those analyzing variables such as gender, age, tenure, morality and attachment to the organization have produced mixed results. Below, we propose how an identitybased approach to whistle-blowing is not only consistent with what we know about the individual-level factors in the literature but may also help resolve the contradictory findings and offer possible avenues for future research.

\section{IDENTITY AND WHISTLE-BLOWING}

Identity is rooted in the very core of one's being and involves being true to oneself in action (Erikson, 1964). One's identity or the way in which one views oneself has been shown to affect one's cognition, judgments, affect, and behaviors (see Burke, 1980; Marks, 1977; Stryker, 1987; Tajfel \& Turner, 1979), including those related to morality. For example, moral identity defined as a "self-conception organized around a set of moral traits" (Aquino \& Reed, 2002: 1424) has been found to positively influence volunteering decisions and donations of food to help the 
needy (Aquino \& Reed, 2002). Also, Skitka and Mullen (2002) showed that when situations prime individuals' personal identities with social justice concerns by posing a threat to a moral value they hold especially dear, they behaved in accordance with their moral mandates associated with those values. This line of research, thus, suggests that identity plays a significant role in affecting individuals' moral judgments and behaviors. One implicit consequence of this work is that identity is likely to influence a morally significant process such as whistle-blowing.

We maintain that an identity focus may help account for the consistent findings and explicate the inconsistent findings in the whistle-blowing literature. Hence, we propose that an identity approach allows us to capture a more dynamic part of human nature that takes into account situational and temporal changes as outlined below, rather than the conventional dispositional approach, which assumes that particular individual characteristics (e.g., gender, education) have constant and predictable relationships to whistle-blowing (Markus \& Wurf, 1987). Additionally, identity may serve as a proximal variable to whistle-blowing, in comparison to demographic characteristics such as age, gender and tenure which may be more distal. Distal factors are generally more likely to influence intentions behind actions, while proximal variables influence the actions themselves (Kanfer, 1992). Therefore, we argue that identity may be involved in translating intentions into behavior. For instance, instead of age and moral development, one's moral identity (Aquino \& Reed, 2002) may be a more proximal predictor of one's decision to blow the whistle. The former factors have traditionally been associated with one's ability to make moral decisions. However, these variables overlook what individuals mean by "being moral," which is a probable reason for the current contradictory findings. Adopting the character perspective of moral identity (Shao, Aquino, \& Freeman, 2008), by situating the notion of morality within the individual as a component of the self, as opposed to the situation, will help researchers tackle the actions/behaviors that individuals consider "moral" and, in turn, the traits that characterize one's moral identity. An examination of the content of one's identity may thus help us understand some of the individual-level antecedents (specifically, demographic characteristics) of whistle-blowing.

Furthermore, as evident from Enron whistleblower Sherron Watkins' s chronicles (Swartz \& Watkins, 2003) in the Power Failure: The Inside Story of the Collapse of Enron, one may decide to blow the whistle after taking into account one's relationship with (and the effect of whistleblowing on) several actors such as one's organization, supervisors, subordinates, colleagues and peers, and even one's family. However, the current work on whistle-blowing largely focuses on the individual-organizational bond to explain one's motivation to blow the whistle. As implied by the arguments about loyalty discussed above, individuals' sense of self is not fully encapsulated by their attachment with the organization since individuals have multiple simultaneous identities (Burke, 1937; Mead, 1934; Pratt \& Rafaeli, 1997) and identifications (Ashforth \& Mael, 1989; also see Pratt, 1998). These identities are derived from being members of groups (social identities), having certain roles (role identities), or possessing certain characteristics (personal identities). Some theorists (e.g., Stryker, 1980; Stryker \& Serpe, 1982) argue that these multiple identities are organized in a "salience hierarchy" where salience is the probability that a given identity will be invoked across a variety of situations. In this conceptualization, identity salience is viewed as "transsituational" (Stryker, 1987) and is carried by persons as they move across situations and respond to particular situations. Therefore, choice of behavior is a function of the relative salience of identities to which the behavioral choices are related. 
In addition, identities are often formed, enacted, and exert their influence in the context of certain environmental pressures or particular roles the individual finds him/herself in. In the case of whistle-blowing, identities that are not necessarily relevant to the situation but that have moral components (e.g., certain non-work role identities, such as an identity as a parent) are most likely to be invoked because they are most likely to be at the top of the salience hierarchy in this situation. These identities would, in turn, shape how one responds to the wrongdoing and whether or not they blow the whistle. The decision to blow the whistle is thus not only influenced by one's moral identity and work identity, but may also be influenced by the other identities the individual holds that have moral components. In other words, these non-work related identities are likely to become salient when faced with the decision to report the questionable work activity.

Consider, for example, an individual with a salient moral identity who strongly identifies with her organization and who is a parent of two young children. When this individual observes ethical misconduct in an organization, it would be difficult to predict if she would engage in whistle-blowing based on the extant research on whistle-blowing. Would she blow the whistle because of her salient moral identity? Or would she report the wrongdoing because of her desire to set a good example for her children? Or would she not engage in whistle-blowing because she would not want to risk losing her job? And how will her identification with the organization interact with her personal (moral) identity and role (parent) identity to influence her decision to engage in whistle-blowing? We propose that only a systematic exploration of the "salience hierarchy"-understanding which identities are most salient for the individual when faced with a moral decision-will help investigate if and why this individual will engage in whistle-blowing.

Finally, several scholars (e.g., Burke, 2003; Deaux, 1993; Stets, 1995), building on the work on identity salience, have suggested that multiple identities might work together based on the commonality of the content of these identities. Identities that overlap in their content are more likely to be located near the top of the salience hierarchy and may work together when the situation activates any one of these identities (Deaux, 1993). Therefore, this line of work claims that it is not only the salience or hierarchical organization of the multiple identities but also the shared content among identities which are activated that influence behavior.

We suggest that uncovering the role of multiple identities and identifications as related to whistle-blowing may help clarify the conflicting findings noted above. Consider the contradictory perspectives about loyalty or one's attachment to the organization. These ambiguities in the literature can be resolved if one looks at the multiple identities that the whistle-blower holds and his or her connections to these identities. For instance, the individual in the hypothetical example noted above exhibits a high level of identification with the organization; however, when faced with the dilemma of blowing the whistle in light of an organizational transgression, she may need to seek out additional information, focusing on the implications of whistle-blowing in relation to work- and nonwork-based identities. For example, being a parent, the individual may also be concerned with providing for his family, and may thus be hesitant to take action that may jeopardize his job. Therefore, even though the individual strongly identifies with the organization, she would be less likely to blow the whistle. The inconsistent findings regarding one's attachment to the organization can thus be clarified by 
systematically examining the multiple identities one holds. And it may be the interplay of, and connection between, these identities that could predict the behavior of that potential whistleblower. In a similar line of thought, Weaver and Agle (2002) theorized how individuals' religious identities and associated ethical tendencies compete with organizationally defined identities to differentially affect ethical behavior, thereby suggesting that a key factor in ethical decisionmaking is the commonality of the content of identities.

Also consider a scenario wherein the moral identity of this individual (from the above example) is highly salient. In this case, it is the salience of that one identity that is likely to drive behavior. Shao and colleagues (Shao et al., 2008) make similar arguments to explicate the social-cognitive perspective of moral identity. In addition, Skitka (2003) states that what individuals consider as fair or unfair will depend on which aspect of the self (material, social, or personal and moral) dominates the working self-concept in that situation. Therefore, solely looking at the individualorganizational relationship to understand the motives behind whistle-blowing may not provide us with any conclusive evidence.

The identity perspective is, therefore, an ideal framework to shed light on the individual-level motivations behind whistle-blowing. As illustrated above, investigation of the content of identities ( e.g., moral identity) may help us build on consistent results and clarify findings regarding demographic variables such as age and moral development, while examination of the salience of hierarchical organization of multiple identities and multiple identifications may aid in elucidating the results about tenure, attachment, and other inconsistent factors. Future research adopting this approach should explore ways to reconcile some of the divergent viewpoints about the motives behind whistle-blowing and also extend the current work by offering new and relevant micro-level factors influencing individuals to blow the whistle.

\section{SITUATIONAL ANTECEDENTS OF WHISTLE-BLOWING}

In the prior section, we focused on understanding the individual-level factors that shape whistleblowing. However, individuals do not act inside a vacuum; contextual factors also play a critical role in the decision to blow the whistle. In this section, we broadly consider ( a) characteristics of the job or organization and (b) characteristics of the perceived wrongdoing as two situational variables that are associated with the decision to blow the whistle. Research on situational variables and whistle-blowing displays fairly consistent results.

Characteristics of the Job/Organization

\section{Perceived Support}

Perceived support from top management and from supervisors predicts both whether and how the whistle is blown (Dworkin \& Baucus, 1998). The theoretical arguments here are based on social exchange theory, which suggests that high level of supervisor support leads to norms of reciprocity which develop trust in the channel an individual can use to report unethical practices. King (1997) confirmed these arguments in his study involving a scenario-based questionnaire of 261 registered nurses in which closeness to supervisor was shown to be positively related to internal whistle-blowing. Similarly, Sims and Keenan (1998) showed that external 
whistleblowing was significantly related to supervisor support for external whistle-blowing. Miceli and Near (1988), in the above noted study, found that whistle-blowing was more likely to occur when observers of wrongdoing were employed by organizations perceived by others to be responsive to complaints.

\section{Organizational Justice}

Organizational features such as organizational justice and organizational climate or culture have also been linked to whistle-blowing (Miceli \& Near, 1985, 1988; Rothschild \& Miethe, 1999; Seifert, 2006; Sims \& Keenan, 1998; Trevino \& Youngblood, 1990). Goldman (2001), in his study on filing of discrimination claims to external agencies, illustrated that distributive and procedural justice within organizations were negatively associated to external whistle-blowing. Based on a quasi-experiment involving a sample of 273 auditors and 244 management accountants, Seifert (2006) uncovered that the highest perceived likelihood of internal whistleblowing occurred when all whistle-blowing circumstances (i.e., distributive, procedural and interactional justice) were fair; and the opposite was found when all whistle-blowing circumstances were unfair. Interestingly, in mixed fairness whistle-blowing situations, a higher perceived likelihood of reporting was expected and found when outcomes were fair versus when they were not fair. Finally, Victor and colleagues (Victor et al., 1993) provided evidence indicating that inclination to report a peer for theft was associated with procedural justice perceptions; however, actual reporting behavior was associated with retributive justice evaluations. This stream of research, therefore, indicates that when organizations are perceived to be fair, observers are more likely to blow the whistle internally and less likely to engage in external whistle-blowing.

\section{Organizational Climate/Culture}

Regarding organizational climate and culture, research shows that individuals in organizations with team or friendship climates, strong ethical climates, or democratic climates are more likely to engage in whistle-blowing when they observe a wrongdoing. For instance, Rothwell and Baldwin (2007) obtained data from 198 police officers and 184 civilian employees in Georgia and reported that a friendship or team climate among police officers in the state of Georgia generally explained willingness to blow the whistle (but not the actual frequency of blowing the whistle). Zhang et al. (2009), in a study on internal whistle-blowing in China, showed that for would-be whistleblowers, organizational ethical culture, by and large, enhanced the expected efficacy of their whistle-blowing intention by providing collective norms concerning legitimate, management-sanctioned behavior. Lastly, the Rothschild and Meithe (1999) study discussed above claimed that ethical climate, in terms of democratic culture, was positively associated with whistle-blowing.

\section{Other Organizational Characteristics}

Organizations that report high incidences of whistle-blowing are also more likely to report higher organizational performance, to have slack resources, to be relatively non-bureaucratic, and tend to operate in public rather than private or not-for-profit sectors (see Mesmer-Magnus \& Viswesvaran, 2005). For instance, Brewer and Selden (1998), in their study on whistle-blowing 
among federal civil servants, showed that federal whistle-blowers tended to work in high performing work groups and organizations. Based on data from national surveys aimed at specific industries and organizations followed by telephonic interviews, Rothschild and Meithe (1999) inferred that whistle-blowing was more frequent in the public sector than in the private sector.

\section{Characteristics of the Wrongdoing}

Characteristics of the wrongdoing have also been shown to have significant implications in the decision to blow the whistle. These characteristics include the type of wrongdoing and the perceived severity of the wrongdoing (Mesmer-Magnus \& Viswesvaran, 2005; Near \& Miceli, 1996). This body of research stems from work claiming that wrongdoing that harms the organization and/or the co-workers is more likely to be reported if strong norms of reciprocity and social support exist between the whistle-blower and the organizational members. Lee and colleagues (Lee et al., 2004) analyzed data obtained from 1952 female respondents who had experienced sexual harassment in the past twenty-four months working in the executive branch of the federal government. They showed that frequency and length of sexual harassment predicted whistle-blowing directly, and also indirectly by affecting the types of sexual harassment. That is, as frequency and length of sexual harassment increased, so did the different types of sexual harassment practices, thereby influencing whistle-blowing. The existence of multiple harassers was also directly and positively related to whistle-blowing. In a similar vein, Near and colleagues (Near, Van Scotter, Rehg, \& Miceli, 2004) found that employees who observed perceived wrongdoing involving mismanagement, sexual harassment, or unspecified legal violations were significantly more likely to report the wrongdoing than were employees who observed stealing, waste, safety problems, or discrimination. Therefore, type of wrongdoing is significantly related to the likelihood of whistle-blowing. A related study by Wise (1995), involving a quasi-experiment with students, demonstrates that harm perceptions positively influenced whistle-blowing intentions.

Although the existing research on the situational antecedents of whistle-blowing has furthered our knowledge of the likelihood of whistle-blowing, it is still unclear which particular organizational practices and policies encourage whistle-blowers to report unethical practices. In fact, we find it surprising that work on whistle-blowing and that on ethics programs have progressed independent of each other, especially since the Ethics Resource Center (2007) survey showed that, in some organizational contexts, formal ethics and compliance programs had a greater impact on reporting behaviors than organizational ethical culture. That is, "in companies with strong ethical cultures, only 35 percent of employees whose companies have little or no ethics and compliance program report the misconduct they observed, compared to 66 percent of employees whose companies have well-implemented ethics and compliance programs" (Ethics Resource Center, 2007: 12). Additionally, the survey uncovered that companies with weak ethical cultures and well implemented ethics and compliance programs had the highest rates of whistle-blowing-perhaps because the lack of an ethical culture leaves no alternative but whistleblowing in response to ethical problems. Therefore, below we propose and elaborate how research on ethics programs can add to our knowledge of whistle-blowing in organizations.

\section{ETHICS PROGRAMS AND WHISTLE-BLOWING}


Following the corporate scandals and the passage of the U.S. Sarbanes-Oxley Act in 2002, organizations are increasingly adopting ethics programs. These ethics programs are designed and implemented in various forms. For example, ethics programs in organizations may include written standards of conduct, training on ethics, mechanisms to seek ethics advice or information, means to report misconduct anonymously, discipline of employees who violate ethical standards, and evaluation of employees' performance based on ethical conduct (Weaver, Trevino, \& Cochran, 1999b). Additionally, the extent of adoption and effectiveness of ethics programs differs across organizations (Weaver, Trevino, \& Cochran, 1999a). For instance, on one hand, some organizations may espouse a code of ethics and ensure that all organizational members understand and follow their codes. On the other hand, other organizations may circulate codes of ethics without explaining the content or communicating the importance of the codes to its members. Similarly, ethics training in organizations can range from filling out short surveys online to intense workshops with regular feedback and counseling. Thus, organizations vary largely on how they form, design, communicate, implement and follow through ethics programs (see Vadera \& Aguilera, 2009). In fact, the study on workplace ethics by the Ethics Resource Center (2007) found that only one in four companies had a well structured and well implemented ethics program, whereas 45 percent of the surveyed companies had a poorly implemented program, with the remaining 30 percent had no ethics program in place whatsoever.

Research on ethics programs can greatly inform us about the situational factors that influence individuals' decision to blow the whistle, especially since in companies with comprehensive ethics and compliance programs, only 29 percent of employees fail to report misconduct they observe, in contrast to 61 percent in companies with no formal ethics and compliance programs (Ethics Resource Center, 2007). For example, Jackson (2000), in a cross-national study of ethics programs, found that despite significant national differences across several arenas of ethical misconduct, the clarity of corporate policy about ethics had little influence on managers' reported ethical decision making. However, Jackson (2000) also showed that the perceived behavior of managers' colleagues was far more important in predicting attitudes toward ethical decisionmaking of managers across the nationalities surveyed. This finding is not surprising given the recent research on whistle-blowing which shows that role models, partners, and "significant others" act as "organizational loyalty disrupters" that facilitate decisions to blow the whistle by altering individuals' cost-benefit analyses and perceived value conflicts (Henik, 2008). Indirect support for this argument can also be found in studies that have obtained a positive relationship between subjective norms and whistle-blowing (Ellis \& Arieli, 1999; Park \& Blenkinsopp, 2009). Therefore, simply implementing an ethics program in an organization may not be sufficient to encourage employees to report unethical practices. In fact, as the study by Jackson (2000) illustrated, even effective communication of ethics programs may be inadequate to encourage employees to blow the whistle. Instead, intervening in peer dynamics, rather than ensuring that ethics programs are enforced in organizations, may have more influence on whistle-blowing. A comprehensive integration of research on whistle-blowing and ethics programs would thus help us understand better the organizational facilitators of whistle-blowing.

Furthermore, Weaver and Trevino (1999) conducted a field survey in a large financial services company to investigate the relationships of the values and compliance orientations in an ethics program to a diverse set of outcomes such as commitment, integrity, etc. Employees' perceptions 
that the company ethics program was oriented toward affirming ethical values were associated with seven outcomes of reporting violation, commitment, integrity, ethical awareness, better decision making, seeking advice, and observing ethical behavior. Perceptions of a compliance orientation were associated with the latter four of these outcomes. The interaction of values and compliance orientations was associated with employees' willingness to report misconduct. This suggests that organizations need to implement more comprehensive ethics programs that call into attention not only employees' obligations to their organizations but also those exhibiting the organizational ethical values. However, no research, as per our knowledge, has looked systematically at the role of morality and role responsibility in the formulation of ethics programs (see Reynolds \& Bowie, 2004, for a similar call to design ethics programs from a moral point of view), though both of these factors have been shown to act as motives for individuals engaging in whistle-blowing.

We maintain that an examination of how ethics programs influence whistleblowing can inform us of the complexities of designing organizational systems that motivate individuals to blow the whistle. Effective formulation, communication and implementation of very simple ethics programs may not be sufficient to motivate individuals to blow the whistle. Whistle-blowing is a complex process and organizations need to develop more encompassing ethics programs to ensure that unethical practices are reported. Also, incorporating research on ethics programs with that on whistle-blowing may highlight (1) why individuals are more likely to report certain crimes in comparison to others and (2) what the channels (internal versus external) individuals are more likely to chose to blow the whistle, since organizational ethics programs may be designed to encourage practices or may be communicated in ways that may underscore certain options over others.

Below, we discuss the methodological challenges faced by researchers in addressing the foregoing questions and issues, and argue that some of the inconsistent findings can be resolved, and new research avenues investigated using multi-method approaches to research on whistleblowing.

\section{METHODOLOGICAL ISSUES}

Our review of the whistle-blowing literature shows that most of the research on whistle-blowing has mainly been conducted using either cross-sectional self-reported surveys or scenario-based studies. As it is well-known, these two methodologies have some inherent limitations, thereby restricting our knowledge of the individual and situational antecedents of whistle-blowing. Cross-sectional, self-reported surveys (e.g., Miceli \& Near, 1984, 1988), although easy to administer, cannot be employed to examine casual relationships. This method is also at risk of monomethod bias wherein the magnitude of the observed relations could be inflated due to common source variance. Also, respondents are more likely to exhibit social desirability bias and hypothesis-guessing when asked to respond to surveys (Fowler, 2001). In quasi-experiments, including scenario-based studies, subjects are usually presented with stories describing the wrongdoing in different experimental conditions and are asked how they would respond to the wrongdoing described in the scenario (Keenan, 2000; Sims \& Keenan, 1998; Wise, 1995). This methodology helps maintain anonymity, avoids same source biases, and gets closer to understanding causality. However, respondents may become victims of social desirability biases 
and may be susceptible to experimenter demand bias in which they give the researcher the answers they believe would help him/her. In addition, it is difficult to assess if individuals responding to the scenarios would behave in a similar manner when faced with an equivalent situation in the "real" world. Hence, most case-based studies (e.g., Kaplan, Pany, Samuels, \& Zhang, 2009; Peek, Roxas, Peek, Robichaud, Salazar, \& Codina, 2007; Sims \& Keenan, 1998) measure factors affecting the "intentions" to blow the whistle instead of the actual act of whistleblowing.

Another reason for the lack of significant progress in the field of whistle-blowing involves the implementation of flawed research designs in many studies. We acknowledge that these errors are likely to be associated with the difficulty of controlling for all the possible factors that may influence the decision to blow the whistle in a single study, and of finding an organization that would allow collecting sensitive data on whistle-blowing and related issues. However, an inaccurate design limits deeper and thorough understanding of the different forces affecting the decision to blow the whistle. For instance, to analyze the moderating role of locus of control on the relationship between ethical judgment and whistle-blowing intention, Chui (2003) distributed 800 copies of a questionnaire to managers and professionals studying in various part-time MBA programs in China. To measure whistle-blowing, respondents were asked questions about ethicality of a situation in which a manager was thinking about blowing the whistle on major corruption that he had observed in his company. Apart from the variables that were central to his study, Chui measured some demographic variables as controls. However, unfortunately these controls still do not account for all the different individual and organizational forces which might influence whistle-blowing. ${ }^{2}$ A more "fool-proof method may have been to collect more individual-level data from the respondents as well as to conduct the study in a single organization thereby increasing the validity of the findings (see Zhang et al., 2009 for another research that can benefit from a better design).

In Miceli, Near, and Dworkin's (2008) discussion of the pros and cons of several methodologies adopted to conduct whistle-blowing research, they proposed a twofold solution to methodological shortcomings. First, they argued that "researchers must make careful trade-offs to address methodological dilemmas" (Miceli, Near, \& Dworkin, 2008: 31) and that the researchers should articulate the likely consequences of the trade-offs while presenting their research. Second, Miceli and colleagues requested editors and reviewers to become more familiar with dilemmas in whistle-blowing research and to be more supportive of researchers who take appropriate care. We recommend that the best way to understand the precursors to whistle-blowing and to extend prior work is by adopting a mixed methods design (Creswell \& Plano Clark, 2007). This research design involves combining qualitative and quantitative approaches in all stages of the study-formulation of research questions, data collection procedures and research method, and interpretation of the results to make final inferences. In multi-method designs, either parallel (concurrent mixed model design) or sequential (sequential mixed model design) strands are adopted in which inferences of one strand lead to questions of the next strand or the data from one strand are converted and analyzed again to answer different questions (see Tashakkori \& Teddlie, 2003).

\footnotetext{
${ }^{2}$ Chui notes some of these limitations in the discussion section of his article.
} 
Adoption of multi-method designs can, therefore, grant simultaneously the advantages of quantitative and qualitative research to a given study. For instance, if investigators were to conduct semi-structured interviews after administering surveys, they would be able accomplish three additional objectives in the study: (a) clear up ambiguous relationships, if any, in the survey; (b) elaborate on the processes and mechanisms that underlie the proposed framework; and even (c) look at factors that are difficult to explore in surveys. Researchers can use the strengths of an additional method to overcome the weaknesses in another method by employing both in a research study.

\section{DISCUSSION}

Our primary objective in this review article was to address the consistent and inconsistent findings regarding the individual and situational antecedents of whistleblowing, with the aim of paving the way for future research in the area. Research has shown that some individual-level factors such as job performance, organizational performance, and education consistently predict whistle-blowing behavior, while demographic variables (such as gender, age, tenure, etc.) and one's attachment to the organization (such as job commitment, organizational commitment, etc.) have produced some mixed findings. Based on this review, we propose that to resolve these conflicting results regarding the individual antecedents, and to extend this work in a more systematic manner, we need to adopt an identity lens to understand why individuals engage in whistle-blowing. Identity research suggests that individuals have multiple identities, and thus, multiple identifications. We argue that understanding (a) the content of identities, (b) the salience or hierarchical organization of said multiple identities, and/or (c) one's connection to the multiple identities (through multiple identifications) may help us explain why individuals engage in whistle-blowing.

In contrast, research regarding the situational antecedents of whistle-blowing has revealed more consistent findings. But we contend that even though we have some knowledge about the situational factors influencing an individual's engagement in whistle-blowing, this research is limited because it does not account for the role of ethics programs in organizations which are becoming increasingly prevalent. According to the Sarbanes-Oxley Act of 2002, organizations are required to take more responsibility for detecting and reducing fraud and ensuring that whistle-blowers are not retaliated against for their actions. Organizations around the world are increasingly adopting ethics programs to fulfill these criteria. But we still do not fully know in what ways these ethics programs facilitate whistle-blowing. Some preliminary evidence (see Weaver \& Trevino, 1999; Weaver, Trevino, \& Cochran, 1999a, b) points out that a combination of compliance- and values-based programs is most likely to promote internal whistle-blowing, but research in this arena is largely inadequate and much required.

Future Research

Apart from the insights generated from the identity and ethics programs literatures, our understanding of whistle-blowing can also be strengthened if we focus on three additional avenues. These include (a) viewing whistle-blowing as a form of positive deviance, (b) developing a mesa-level theory of whistle-blowing, and (c) systematically accounting for the role of national cultures and laws to gamer a holistic understanding of the process of whistle-blowing. 


\section{Whistle-Blowing as Positive Deviance}

As an avenue for future research, we suggest conceptualizing whistle-blowing as positive deviance as a means to develop a comprehensive understanding of both the individual and the situational antecedents of whistle-blowing. Positive, or constructive, deviance is defined as intentional behaviors that depart from the norms of a referent group in honorable ways (Galperin \& Burke, 2006; Spreitzer \& Sonenshein, 2004; Warren, 2003). Referent groups can include the workgroup, the department, the organization, and even the society as a whole, and honorable ways mainly involve behaviors which promote the welfare of the organization and its various stakeholders. Given the low rates of the whistle-blowing practice in organizations (as illustrated in the introduction), whistle-blowing can be equated with positive deviance because both behaviors entail deviating from the norms of the referent groups and acting in ways that have maximal benefit for the organization and its stakeholders. Viewing whistle-blowing as positive deviance could potentially benefit scholars and researchers by setting the stage to "lump," rather than "spilt" (Fiske, 2006) across literatures to gain a deeper understanding of the antecedents of whistle-blowing and positive deviance. By "lumping," we mean integration of concepts and ideas that fall under a common rubric or umbrella. This integrative theory and research would then aid scholars to draw lessons for understanding both the specific manifestations of whistle-blowing and the general phenomenon of positive deviance. It would also enable scholars to pursue research in specific areas such as whistle-blowing with a sense of the general dynamics involved (see Grant \& Ashford, 2008), thereby extending the scope of theoretical and methodological horizons of research on whistle-blowing.

\section{Meso-Level Theory of Whistle-Blowing}

Another arena for future research could include an integration of the micro (individual) and the macro (situational) factors influencing whistle-blowing to develop a "meso" (Rousseau, 1985) theory of whistle-blowing. Meso- or multi-level theories and designs have garnered substantial attention in recent years (Mathieu \& Taylor, 2007). The basic tenant of meso-level thinking is that to gain a true understanding of a phenomenon, theory and measurement should be aligned to account for the relationships between variables across levels (i.e., individual, group, organizational, societal/institutional). For instance, meso-level models may advance a theory by considering relationships that navigate levels of analysis, such as influence of group climate on individual performance (Hofmann, Morgeson, \& Gerras, 2003). We propose that research in the future should adopt a similar approach by exploring how ethics programs in organizations interact with one's identity to affect one's engagement in whistle-blowing. For instance, it would be interesting to investigate if values- (versus compliance-) based ethics programs in organizations facilitate employees with a salient moral identity to blow the whistle or if a compliance-based program is likely to encourage those with a strong identification with the organization to engage in whistle-blowing. Hence, future research could be conscious of how micro-level variables such as identity interact with macro-level notions such as those of ethics programs to influence whistle-blowing. 
Future research can take the level of analysis even higher in order to examine the role of national cultures and laws on whistle-blowing. For instance, Peek and colleagues (Peek et al., 2007) showed business students from the NAFTA countries a possible sexual harassment scenario from Arthur Andersen's Business Ethics program. The students were asked to consider whether the characters should report the possible harasser to their supervisor. Peek and colleagues developed hypotheses for the three countries based on Hofstede's (1980) cultural dimensions but found unexpected significant differences. To our knowledge, this study is among the very few empirical articles to explore differences in national culture on whistle-blowing. This scant research suggests that a more comprehensive and systematic analysis is required to understand how national culture influences whistle-blowing. One way to capture national differences is to examine how law and its enforcement facilitate whistle-blowing across countries. For example, the U.S. Sarbanes-Oxley act of 2002 has dramatically affected organizations and has pushed them to enforce and encourage whistle-blowing in the U.S. However, such hard regulation is largely missing in countries across the world. For example, some studies found that in countries like India, the attitudes toward, and pressures for, successful implementation of ethics programs were significantly lower than those in the U.S. (Chakraborty, 1997). Therefore, future research needs to investigate how national differences in laws and their enforcement, along with cultural dimensions and other country-level institutional factors such as employment relations and understanding of trust endorse whistle-blowing.

\section{CONCLUSION}

Having reviewed the extant literature on whistle-blowing, we note that although the field is progressing, it is restricted and plagued with inconsistent findings especially regarding individual-level antecedents to whistle-blowing. As a result of these inconsistencies, we still do not have adequate knowledge of the motives of potential whistle-blowers. Research involving the role of situational precursors has also been limited since scholars have left out a systematic synthesis of the work on ethics programs and whistle-blowing. We urge scholars to first address the challenges put forth by these inconsistencies and inadequacies. In this review article, we provide the first step in this direction by laying the groundwork for exploring new, exciting, and fruitful avenues of research on the individual and situational antecedents of whistle-blowing.

\section{NOTE}

We wish to thank the $B E Q$ editors, Gary Weaver and Marshall Schminke, as well as Greg Oldham, Mike Pratt, Deborah Rupp, and Gretchen Winter for their helpful comments on earlier drafts and ideas included in this review. We also thank the Center for Professional Responsibility in Business and Society at the University of Illinois, Urbana-Champaign, for its financial support.

\section{REFERENCES}

Aquino, K., \& Reed, A. 2002. The self-importance of moral identity. Journal of Personality and Social Psychology, 83(6): 1423-40.

Ashforth, B. E., \& Mael, F. A. 1989. Social identity theory and the organization. Academy of Management Review, 14: 20-39. 
Association of Certified Fraud Examiners. 2006. Report to the nation on occupational fraud and abuse. Austin, TX.

Brewer, G. A., \& Selden, S. C. 1998. Whistleblowers in the federal civil service: New evidence of the public service ethic. Journal of Public Administration Research and Theory, 8(3): 413-39.

Burke, K. 1937. Attitudes towards history. New York: New Republic. . 2003. Relationships among multiple identities. In P. J. Burke, T. J. Owens, R. T. Serpe, \& P. A. Thoits (Eds.), Advances in identity theory and research. New York: Kluwer Academic/Plenum Publishers.

Burke, P. J. 1980. The self: Measurement requirements from an interactionist perspective. Social Psychology Quarterly, 43(1): 18-29.

Chakraborty, S. K. 1997. Business ethics in India. Journal of Business Ethics, 16: 1529-38.

Chiu, R. K. 2003. Ethical judgment and whistleblowing intention: Examining the moderating role of locus of control. Journal of Business Ethics, 43: 65-74.

Creswell, J. W., \& Plano Clark, V. L. 2007. Designing and conducting mixed methods research. Thousand Oaks, CA: Sage.

Deaux, K. 1993. Reconstructing social identity. Personality and Social Psychology Bulletin, 19: 4-12.

Dozier, J. B., \& Miceli, M. P. 1985. Potential predictors of whistle-blowing: A prosocial behavior perspective. Academy of Management Review, 10: 823-36.

Dworkin, T. M., \& Baucus, M. S. 1998. Internal vs. external whistle-blowers: A comparison of the whistleblowing processes. Journal of Business Ethics, 17: 1281-98.

Ellis, S., \& Arieli, S. 1999. Predicting intentions to report administrative and disciplinary infractions: Applying the Reasoned Action model. Human Relations, 52: 947-67.

Erikson, E. H. 1964. Insight and responsibility. New York: Norton.

Ethics Resource Center. 2007. National business ethics survey: An inside view of private sector ethics. Arlington, VA: Ethics Resource Center.

Fiske, S. T. 2006. Building bridges inside and outside social psychology: A case for lumpingneatly. In P. A. M. V. Lange (Ed.), Bridging social psychology: Benefits of transdisciplinary approaches: 47-51. Mahwah, NJ: Lawrence Erlbaum Associates.

Fowler, F. J. 2001. Survey research methods. Thousand Oaks, CA: Sage.

Galperin, B. L., \& Burke, R. J. 2006. Uncovering the relationship between workaholism and workplace destructive and constructive deviance: An exploratory study. International Journal of Human Resource Management, 17: 331-47.

Goldman, B. 2001. Toward an understanding of employment discrimination claiming: An integration of organizational justice and social information processing theories. Personnel Psychology, 54: 361-86. 
Grant, A. M., \& Ashford, S. J. 2008. The dynamics of proactivity at work. Research in Organizational Behavior, 28: 3-34.

Henik, E.G. 2008. Mad as hell or scared stiff? The effects of value conflict and emotions zon potential whistle-blowers. Unpublished doctoral dissertation, University of California, Berkeley.

Hernandez, V. 2008. Whistle-blowing nets federal government $\$ 9.3$ billion from fraudulent health care providers, All Headline News. www.allheadlinenews.com/articles/7012144721, September 2.

Hofmann, D. A., Morgeson, F. P., \& Gerras, S. J. 2003. Climate as a moderator of the relationship between leader-member exchange and content specific citizenship: Safety climate as exemplar. Journal of Applied Psychology, 88: 170-78.

Hofstede, G. 1980. Culture's consequences: International differences in work related values. Beverly Hills, CA: Sage.

Hollander, E. P. 1958. Conformity, status, and idiosyncratic credits. Psychological Review, 65: 117-27.

Hudson Employment Index. 2005. One in three workers witness ethical misconduct despite clearly communicated guidelines. Washington, DC: Hudson.

Jackson, T. 2000. Management ethics and corporate policy: A cross-cultural comparison. Journal of Management Studies, 37: 349-69.

Kanfer, R. 1992. Work motivation: New directions in theory and research. In C. L. Cooper \& I. T. Robertson (Eds.), Internal review of industrial and organizational psychology, vol. 7: 1-53. Chichester, England: Wiley.

Kaplan, S., Pany, K., Samuels, J., \& Zhang, J. 2009. An examination of the association between gender and reporting intentions for fraudulent financial reporting. Journal of Business Ethics, 87: 15-30.

Keenan, J.P. 2000. Blowing the whistle on less serious forms of fraud: A study of executives and managers. Employee Responsibilities and Rights Journal, 12: 199-217.

King, G. I. 1997. The effects of interpersonal closeness and issue seriousness on blowing the whistle. Journal of Business Communication, 34: 419-36.

Lee, J.-Y., Heilmann, S. G., \& Near, J.P. 2004. Blowing the whistle on sexual harassment: Test of a model of predictors and outcomes. Human Relations, 57: 297-322.

Marks, S. R. 1977. Multiple roles and role strain: Some notes on human energy, time and commitment. American Sociological Review, 42: 921-36.

Markus, H., \& Wurf, E. 1987. The dynamic self-concept: A social psychological perspective. Annual Review of Psychology, 38: 299-337.

Mathieu, J.E., \& Taylor, S. R. 2007. A framework for testing meso-mediational relationships in Organizational Behavior. Journal of Organizational Behavior, 28: 141-72. 
Mead, G. H. 1934. Mind, self, and society. Chicago: University of Chicago Press.

Mesmer-Magnus, J. R., \& Viswesvaran, C. 2005. Whistleblowing in organizations: An examination of correlates of whistleblowing intentions, actions, and retaliation. Journal of Business Ethics, 62: 277-97.

Miceli, M. P., \& Near, J.P. 1984. The relationships among beliefs, organizational position, and whistle-blowing status: A discriminant analysis Academy of Management Journal, 27:687-705.

1985. Characteristics of organizational climate and perceived wrongdoing associated with whistle-blowing decisions. Personnel Psychology, 38: 525-44.

. 1988. Individual and situational correlates of whistle-blowing. Personnel Psychology, 41: 267-82.

1992. Blowing the whistle: The organizational and legal implications for companies and employees. New York: Lexington.

. 2002. What makes whistle-blowers effective? Three field studies. Human Relations, 55: 455-79.

. 2005. Standing up or standing by: What predicts blowing the whistle on organizational wrongdoing? Research in Personnel and Human Resources Management, 24: 95-136.

Miceli, M. P., Near, J.P., \& Dworkin, T. M. 2008. Whistle-blowing in organizations. New York: Routledge.

Near, J.P., \& Miceli, M. P. 1985. Organizational dissidence: The case of whistle-blowing. Journal of Business Ethics, 4: 1-16.

. 1996. Whistle-blowing: Myth and reality. Journal of Management, 22: 507-26.

Near, J.P., Van Scotter, J., Rehg, M. T., \& Miceli, M. P. 2004. Does type of wrongdoing affect the whistle-blowing process? Business Ethics Quarterly, 14: 219-42.

Park, H., \& Blenkinsopp, J. 2009. Whistleblowing as planned behavior: A survey of South Korean police officers. Journal of Business Ethics, 85: 545-56.

Peek, L., Roxas, M., Peek, G., Robichaud, Y., Salazar, B. E. C., \& Codina, J. N. B. 2007. NAFTA students' whistle-blowing perceptions: A case of sexual harassment. Journal of Business Ethics, 74: 219-31.

Pratt, M. G. 1998. To be or not to be: Central questions in organizational identification. In D. Whetten, \& P. Godfrey (Eds.), Identity in organizations: Developing theory through conversations: 171-207. Thousand Oaks, CA: Sage.

Pratt, M. G., \& Rafaeli, A. 1997. Organizational dress as a symbol of multilayered social identities. Academy of Management Journal, 40: 862-98.

Reynolds, S. J., \& Bowie, N. E. 2004. A Kantian perspective on the characteristics of ethics programs. Business Ethics Quarterly, 14: 275-92. 
Rothschild, J., \& Miethe, T. D. 1999. Whistle-blower disclosures and management retaliation: The battle to control information about organizational corruption. Work and Occupations, 26: $107-28$.

Rothwell, G. R., \& Baldwin, J. N. 2007. Ethical climate theory, whistle-blowing, and the code of silence in police agencies in the state of Georgia. Journal of Business Ethics, 70: 341-61.

Rousseau, D. M. 1985. Issues of level in organizational research: Multi-level and cross-level perspectives. Research in Organizational Behavior, 7: 1-37.

Seifert, D. L. 2006. The influence of organizational justice on the perceived likelihood of whistleblowing. Unpublished doctoral dissertation, Washington State University, Pullman.

Shao, R., Aquino, K., \& Freeman, D. 2008. Beyond moral reasoning: A review of moral identity research and its implications for business ethics. Business Ethics Quarterly, 18: 513-40.

Sims, R. L., \& Keenan, J. P. 1998. Predictors of external whistleblowing: Organizational and intrapersonal variables. Journal of Business Ethics, 17: 411-21.

. 1999. A cross-cultural comparison of managers' whistleblowing tendencies. International Journal of Value-Based Management, 12: 137-51.

Singer, M., Mitchell, S., \& Turner, J. 1998. Consideration of moral intensity in ethicality judgements: Its relationship with whistle-blowing and need-for-cognition. Journal of Business Ethics, 17: 527-41.

Skitka, L. J. 2003. Of different minds: An accessible identity model of justice reasoning. Personality and Social Psychology Review, 7: 286-97.

Skitka, L. J., \& Mullen, E. 2002. Understanding judgments of fairness in a real-world political context: A test of the value protection model of justice reasoning. Personality and Social Psychology Bulletin, 28: 1419-29.

Somers, M. J., \& Casal, J.C. 1994. Organizational commitment and whistle-blowing: A test of the reformer and the organization man hypothesis. Group \& Organization Management, 19: $270-85$.

Spreitzer, G. M., \& Sonenshein, S. 2004. Toward the construct definition of positive deviance. American Behavioral Scientist, 47: 828-47.

Stansbury, J. M., \& Victor, B. 2009. Whistle-blowing among young employees: A life-course perspective. Journal of Business Ethics., 85: 281-99.

Starkey, P. L. 1998. Whistleblowing behavior: The impact of situational and personality variables. Unpublished doctoral dissertation, University of Mississippi.

Stets, J.E. 1995. Modelling control in relationships. Journal of Marriage and the Family, 57: 489-501.

Stryker, S. 1980. Symbolic interactionism: A social structural version. Palo Alto, CA: Benjamin/Cummings. 
. 1987. Identity theory: Developments and extensions. In K. Yardley, \& T. Honess (Eds.), Self and identity: Psychological perspectives: 89-103. New York: Wiley.

Stryker, S., \& Serpe, R. T. 1982. Commitment, identity salience, and role behavior. In W. Ickes \& E. S. Knowles (Eds.), Personality, Roles and Social Behavior. New York: SpringerVerlag.

Swartz, M., \& Watkins, S. 2003. Power failure: The inside story of the collapse of Enron. New York: Random House, Inc.

Tajfel, H., \& Turner, J. C. 1979. An integrative theory of intergroup conflict. In W. G. Austin \& S. Worchel (Eds.), The social psychology of group relations: 33-47. Monterey, CA: Brooks-Cole.

Tashakkori, A., \& Teddlie, C. 2003. Handbook on mixed methods in the behavioral and social sciences. Thousand Oaks, CA: Sage.

Trevino, L. K., \& Victor, B. 1992. Peer reporting of unethical behavior: A social context perspective. Academy of Management Journal, 35: 38-64.

Trevino, L. K., \& Youngblood, S. A. 1990. Bad apples in bad barrels: A casual analysis of ethical decision-making behavior. Journal of Applied Psychology, 75: 378-85.

U.S. Merit Systems Protection Board. 1984. Blowing the whistle in the federal government: A comparative analysis of 1980 and 1983 survey findings. Washington, DC: U.S.M.S.P.B.

Vadera, A. K., \& Aguilera, R. V. 2009. The role of IHRM in the formulation and implementation of ethics programs in multinational enterprises. In P. Sparrow (Ed.), Handbook of international human resource management: Integrating people, process, and context: 413-38. New York: Wiley.

Victor, B., Trevino, L. K., \& Shapiro, D. L. 1993. Peer reporting of unethical behavior: The influence of justice evaluations and social context factors. Journal of Business Ethics, 12: 253-63.

Warren, D. 2003. Constructive and destructive deviance in organizations. Academy of Management Review, 28: 622-32.

Weaver, G. R., \& Agle, B. R. 2002. Religiosity and ethical behavior in organizations: A symbolic interactionist perspective. Academy of Management Review, 27: 77-97.

Weaver, G. R., \& Trevino, L. K. 1999. Compliance and values oriented ethics programs: Influences on employees' attitudes and behavior. Business Ethics Quarterly, 9: 315-35.

Weaver, G. R., Trevino, L. K., \& Cochran, P. L. 1999a. Corporate ethics practices in the mid1990's: An empirical study of the Fortune 1000. Journal of Business Ethics, 18: 283-94.

. 1999b. Integrated and decoupled corporate social performance: Management commitments, external pressures, and corporate ethics practices. Academy of Management Journal, 42: 539-52.

Wise, T. D. 1995. An analysis of factors proposed to affect the decision to blow the whistle on unethical acts. Unpublished doctoral dissertation, Louisiana Tech University. 
Zhang, J., Chiu, R. K., \& Wei, L. 2009. Decision-making process of internal whistleblowing behavior in China: Empirical evidence and implications. Journal of Business Ethics, 88: 25-41.

\section{Appendix}

Table 1. Studies Investigating the Antecedents of Whistle-Blowing

\begin{tabular}{|c|c|c|c|c|}
\hline Reference & Key concepts & Key variables & Key predictions and findings & Method and sample \\
\hline $\begin{array}{l}\text { Brewer and } \\
\text { Selden } \\
(1998)\end{array}$ & $\begin{array}{l}\text { Federal Civil } \\
\text { Service; public } \\
\text { service ethic }\end{array}$ & $\begin{array}{l}\text { Public interest } \\
\text { motive; job } \\
\text { performance; job } \\
\text { commitment; job } \\
\text { satisfaction }\end{array}$ & $\begin{array}{l}\text { Federal whistle-blowers (1) were motivated by } \\
\text { concern for public interest; (2) were high } \\
\text { performers; (3) report high levels of job } \\
\text { security, job achievement, job commitment and } \\
\text { job satisfaction; (4) worked in high performing } \\
\text { work groups and organizations }\end{array}$ & $\begin{array}{l}\text { Maximum likelihood } \\
\text { regression using data } \\
\text { from } 1992 \text { Merit } \\
\text { Principles survey } \\
\text { conducted by U.S. Merit } \\
\text { System Protection Board } \\
\text { database }\end{array}$ \\
\hline Chiu (2003) & $\begin{array}{l}\text { Whistle- } \\
\text { blowing } \\
\text { intention }\end{array}$ & $\begin{array}{l}\text { Whistle-blowing } \\
\text { intention; ethical } \\
\text { judgment; locus of } \\
\text { control }\end{array}$ & $\begin{array}{l}\text { For Chinese managers/professionals, the } \\
\text { decision to blow the whistle was associated with } \\
\text { their locus of control and subjective judgment } \\
\text { regarding the intention of whistle-blowing }\end{array}$ & $\begin{array}{l}\text { Regression analysis of } \\
\text { survey data collected } \\
\text { from } 360 \text { Chinese } \\
\text { managers/professionals }\end{array}$ \\
\hline $\begin{array}{l}\text { Dworkin } \\
\text { and Baucus } \\
(1998)\end{array}$ & $\begin{array}{l}\text { Internal vs } \\
\text { external } \\
\text { whistle- } \\
\text { blowing }\end{array}$ & $\begin{array}{l}\text { Gender; tenure; } \\
\text { level of education } \\
\text { or skills; amount of } \\
\text { evidence collected; } \\
\text { seriousness of } \\
\text { harm; effectiveness } \\
\text { of whistle-blowing; } \\
\text { retaliation and } \\
\text { firing }\end{array}$ & $\begin{array}{l}\text { (1) External whistle-blowers had less tenure } \\
\text { with the organization, greater evidence of } \\
\text { wrongdoing, and they tended to be more } \\
\text { effective in changing organizational practices. } \\
\text { (2) External whistle-blowers also experienced } \\
\text { more extensive retaliation than internal whistle- } \\
\text { blowers. (3) Patterns of retaliation by } \\
\text { management against the whistle-blower varied } \\
\text { depending on whether the whistle-blower } \\
\text { reports internally or externally }\end{array}$ & $\begin{array}{l}\text { Cross-tabs using sixty } \\
\text { three legal cases } \\
\text { involving wrongful } \\
\text { firings in violation of a } \\
\text { public policy. Thirty- } \\
\text { three of these involved } \\
\text { internal or external } \\
\text { whistle-blowing }\end{array}$ \\
\hline $\begin{array}{l}\text { Ellis and } \\
\text { Arieli } \\
(1999)\end{array}$ & $\begin{array}{l}\text { Reasoned } \\
\text { action model; } \\
\text { Israeli Defense } \\
\text { Forces }\end{array}$ & $\begin{array}{l}\text { Attitude toward } \\
\text { reporting; } \\
\text { subjective norm; } \\
\text { organizational } \\
\text { responses; public } \\
\text { opinion; job- } \\
\text { intrinsic outcomes }\end{array}$ & $\begin{array}{l}\text { Two proposed predictors, attitude toward } \\
\text { reporting and subjective norm, significantly } \\
\text { predicted intention to report; but the effect of } \\
\text { subjective norm was much stronger than that of } \\
\text { the attitude component }\end{array}$ & $\begin{array}{l}\text { Two samples (166 and } \\
109 \text { each) of Israeli } \\
\text { Defense Forces ground } \\
\text { forces were surveyed } \\
\text { and the data was } \\
\text { analyzed using } \\
\text { regression analysis }\end{array}$ \\
\hline $\begin{array}{l}\text { Goldman } \\
(2001)\end{array}$ & $\begin{array}{l}\text { Discrimination- } \\
\text { claiming; } \\
\text { organizational } \\
\text { justice; social } \\
\text { information } \\
\text { processing; } \\
\text { demographic } \\
\text { variables }\end{array}$ & $\begin{array}{l}\text { Distributive justice; } \\
\text { procedural justice; } \\
\text { social guidance; } \\
\text { race; gender; age; } \\
\text { tenure; education; } \\
\text { discrimination- } \\
\text { claiming }\end{array}$ & $\begin{array}{l}\text { The decision to claim for discrimination was } \\
\text { affected by procedural and distributive justice, } \\
\text { social guidance, minority status, gender, age, } \\
\text { tenure, and education }\end{array}$ & $\begin{array}{l}\text { Logistic regression of } \\
\text { survey data collected } \\
\text { based on initial } \\
\text { decisions to claim in a } \\
\text { sample of } 439 \\
\text { terminated workers who } \\
\text { were surveyed at several } \\
\text { unemployment offices }\end{array}$ \\
\hline
\end{tabular}




\begin{tabular}{|c|c|c|c|c|}
\hline Reference & Key concepts & Key variables & Key predictions and findings & Method and sample \\
\hline $\begin{array}{l}\text { Henik } \\
(2008)\end{array}$ & $\begin{array}{l}\text { Potential } \\
\text { whistle- } \\
\text { blowers; value } \\
\text { conflict; } \\
\text { emotions }\end{array}$ & $\begin{array}{l}\text { Value conflict; } \\
\text { inactive } \\
\text { observation; anger; } \\
\text { fear of retaliation }\end{array}$ & $\begin{array}{l}\text { (1) Anger at wrongful activities drove } \\
\text { individuals to make internal reports to } \\
\text { management. Retaliation by management } \\
\text { shifted individuals' focus away from helping } \\
\text { their organizations or victims and toward } \\
\text { attaining retribution; (2) strongly held values } \\
\text { deemed threatened by the wrongful activities or } \\
\text { management's response propelled individuals to } \\
\text { make external whistle-blowing reports; (3) two } \\
\text { categories of "organizational loyalty disrupters" } \\
\text { facilitated decisions to blow the whistle by } \\
\text { altering individuals' cost-benefit analyses and } \\
\text { perceived value conflicts: role models and } \\
\text { partners, and "significant others"; (4) } \\
\text { individuals did not always conduct cost-benefit } \\
\text { analyses as they decide whether or not to blow } \\
\text { the whistle, and that their analyses were often } \\
\text { inaccurate }\end{array}$ & $\begin{array}{l}\text { Multimethod approach } \\
\text { based on (1) in-depth } \\
\text { interviews covering } \\
\text { sixty whistle-blowing } \\
\text { and "inactive } \\
\text { observation" episodes } \\
\text { analyzed using } \\
\text { qualitative techniques. } \\
\text { (2) The interview data } \\
\text { were followed by } \\
\text { laboratory experiment } \\
\text { that tests the } \\
\text { relationships uncovered } \\
\text { through the interviews }\end{array}$ \\
\hline $\begin{array}{l}\text { Kaplan, } \\
\text { Pany, } \\
\text { Samuels, } \\
\text { and Zhang } \\
(2009)\end{array}$ & $\begin{array}{l}\text { Gender; } \\
\text { reporting } \\
\text { intentions of } \\
\text { fraudulent } \\
\text { financial } \\
\text { reporting }\end{array}$ & $\begin{array}{l}\text { Anonymous and } \\
\text { nonanonymous } \\
\text { reporting channels; } \\
\text { participant's } \\
\text { gender; } \\
\text { perpetuator's } \\
\text { gender }\end{array}$ & $\begin{array}{l}\text { (1) Female participants' reporting intentions for } \\
\text { an anonymous channel were higher than for } \\
\text { male participants; (2) male and female } \\
\text { participants differed in the extent to which they } \\
\text { judge the reduction in personal costs of an } \\
\text { anonymous reporting channel compared to a } \\
\text { non-anonymous reporting channel; and (3) the } \\
\text { reduction in personal costs mediated the } \\
\text { relationship between participant gender and } \\
\text { anonymous reporting intentions }\end{array}$ & $\begin{array}{l}\text { A } 2 * 2 \text { analysis of } \\
\text { variance between- } \\
\text { subjects experimental } \\
\text { design-once using } \\
\text { nonanonymous reporting } \\
\text { intentions as the } \\
\text { dependent measure and } \\
\text { once using anonymous } \\
\text { reporting intentions as } \\
\text { the dependent measure } \\
\text { with } 113 \text { participants } \\
\text { enrolled in an evening } \\
\text { MBA class in a large } \\
\text { university }\end{array}$ \\
\hline $\begin{array}{l}\text { Keenan } \\
(2000)\end{array}$ & $\begin{array}{l}\text { Less serious } \\
\text { fraud; } \\
\text { management } \\
\text { ethics }\end{array}$ & $\begin{array}{l}\text { Organizational } \\
\text { propensity; } \\
\text { individual } \\
\text { propensity; } \\
\text { interpersonal } \\
\text { communication } \\
\text { climate; moral } \\
\text { perceptions; fear of } \\
\text { retaliation; } \\
\text { managerial level; } \\
\text { demographic } \\
\text { variables }\end{array}$ & $\begin{array}{l}\text { A variety of individual, organizational, and } \\
\text { moral perception variables were examined with } \\
\text { mixed support }\end{array}$ & $\begin{array}{l}\text { Data from } 131 \text { self- } \\
\text { reported surveys from } \\
\text { upper-level managers, } \\
188 \text { from middle-level } \\
\text { managers, and } 406 \text { from } \\
\text { lower-level managers } \\
\text { analyzed using step-wise } \\
\text { regression analysis }\end{array}$ \\
\hline King (1997) & $\begin{array}{l}\text { Relational } \\
\text { closeness; issue } \\
\text { seriousness }\end{array}$ & $\begin{array}{l}\text { Severity of } \\
\text { wrongdoing; } \\
\text { internal vs external } \\
\text { whistle-blowing; } \\
\text { interpersonal } \\
\text { closeness }\end{array}$ & $\begin{array}{l}\text { Regardless of the closeness factor and severity } \\
\text { of the wrongdoing, respondents would follow } \\
\text { the proper chain of command in reporting a } \\
\text { wrongdoing }\end{array}$ & $\begin{array}{l}\text { A } 2 * 2 \text { scenario based } \\
\text { questionnaire completed } \\
\text { by } 261 \text { registered nurses } \\
\text { and the data analyzed } \\
\text { using ANOVA and } \\
\text { multiple regressions }\end{array}$ \\
\hline
\end{tabular}




\begin{tabular}{|c|c|c|c|c|}
\hline Reference & Key concepts & Key variables & Key predictions and findings & Method and sample \\
\hline $\begin{array}{l}\text { Lee, } \\
\text { Heilmann, } \\
\text { and Near } \\
(2004)\end{array}$ & $\begin{array}{l}\text { Sexual } \\
\text { harassment; } \\
\text { retaliation; } \\
\text { predictors and } \\
\text { outcomes }\end{array}$ & $\begin{array}{l}\text { Seriousness of } \\
\text { sexual harassment; } \\
\text { frequency and } \\
\text { length of time of } \\
\text { sexual harassment; } \\
\text { multiple harassers; } \\
\text { upper level } \\
\text { harassers; gender; } \\
\text { age; income; } \\
\text { marital status } \\
\end{array}$ & $\begin{array}{l}\text { (1) Frequency and length of sexual harassment } \\
\text { predicted whistle-blowing directly, as well as } \\
\text { indirectly, via number of types of felonious } \\
\text { sexual harassment. (2) The existence of multiple } \\
\text { harassers was directly and positively related to } \\
\text { whistle-blowing. (3) The level of harassers was } \\
\text { negatively and directly related to whistle- } \\
\text { blowing, mediated by number of types of } \\
\text { nonfelonious sexual harassment }\end{array}$ & $\begin{array}{l}\text { Data from } 1952 \text { female } \\
\text { respondents who had } \\
\text { experienced sexual } \\
\text { harassment during the } \\
\text { past twenty-four months } \\
\text { working in the executive } \\
\text { branch of the federal } \\
\text { government analyzed } \\
\text { using Structural } \\
\text { Equation Modeling } \\
\end{array}$ \\
\hline $\begin{array}{l}\text { Miceli and } \\
\text { Near (1984) }\end{array}$ & $\begin{array}{l}\text { Beliefs; } \\
\text { organizational } \\
\text { position; } \\
\text { whistle- } \\
\text { blowing status }\end{array}$ & $\begin{array}{l}\text { Approve of } \\
\text { whistle-blowing; } \\
\text { fear of retaliation; } \\
\text { incentives to } \\
\text { whistle-blow; } \\
\text { awareness of } \\
\text { complaints } \\
\text { channel; } \\
\text { organizational } \\
\text { position }\end{array}$ & $\begin{array}{l}\text { Distinct profiles of whistle-blowers, observers } \\
\text { of wrongdoing and nonobservers emerged and } \\
\text { were tested }\end{array}$ & $\begin{array}{l}\text { ANOVAs using the } \\
1980 \text { U.S. Merit } \\
\text { Systems Protection } \\
\text { Board archival data }\end{array}$ \\
\hline $\begin{array}{l}\text { Miceli and } \\
\text { Near (1988) }\end{array}$ & $\begin{array}{l}\text { Process of } \\
\text { whistle- } \\
\text { blowing; } \\
\text { bystander } \\
\text { intervention; } \\
\text { prosocial } \\
\text { behaviors }\end{array}$ & $\begin{array}{l}\text { Professional status; } \\
\text { work group size; } \\
\text { job responses; } \\
\text { perceived } \\
\text { intractability of } \\
\text { management; } \\
\text { anonymity }\end{array}$ & $\begin{array}{l}\text { Whistle-blowing was more likely when } \\
\text { observers of wrongdoing (1) held professional } \\
\text { positions, (2) had more positive reactions to } \\
\text { their work, (3) had longer service, (4) were } \\
\text { recently recognized for good performance, }(5) \\
\text { were male, }(6) \text { were members of larger work } \\
\text { groups, and (7) were employed by organizations } \\
\text { perceived by others to be responsive to } \\
\text { complaints }\end{array}$ & $\begin{array}{l}\text { ANOVAs and planned } \\
\text { contrasts using the } 1984 \\
\text { U.S. Merit Systems } \\
\text { Protection Board } \\
\text { archival data }\end{array}$ \\
\hline $\begin{array}{l}\text { Miceli and } \\
\text { Near (2002) }\end{array}$ & $\begin{array}{l}\text { Effective } \\
\text { whistle- } \\
\text { blowing }\end{array}$ & $\begin{array}{l}\text { Power; } \\
\text { organizational } \\
\text { dependence on } \\
\text { wrongdoing; } \\
\text { complaint } \\
\text { recipient's power }\end{array}$ & $\begin{array}{l}\text { Whistle-blowers perceive that wrongdoing was } \\
\text { more likely to be terminated when: (1) it } \\
\text { occurred less frequently, was relatively minor in } \\
\text { impact, or had been occurring for a shorter } \\
\text { period; and (2) whistle-blowers had greater } \\
\text { power-reflected in the legitimacy of their roles } \\
\text { and the support of others }\end{array}$ & $\begin{array}{l}\text { Regression Analysis } \\
\text { using the } 1980 \text { U.S. } \\
\text { Merit Systems } \\
\text { Protection Board } \\
\text { archival data; analysis } \\
\text { from } 1046 \text { respondents } \\
\text { of the questionnaires } \\
\text { created and mailed by } \\
\text { the Research Foundation } \\
\text { of the Institute of } \\
\text { Internal Auditors (IIA); } \\
\text { analysis of data from } \\
1952 \text { female respondents } \\
\text { who had experienced } \\
\text { sexual harassment } \\
\text { working in the executive } \\
\text { branch of the federal } \\
\text { government }\end{array}$ \\
\hline
\end{tabular}




\begin{tabular}{|c|c|c|c|c|}
\hline Reference & Key concepts & Key variables & Key predictions and findings & Method and sample \\
\hline $\begin{array}{l}\text { Near, Rehg, } \\
\text { Van Scotter, } \\
\text { and Miceli } \\
(2004)\end{array}$ & $\begin{array}{l}\text { Whistle- } \\
\text { blowing } \\
\text { process; type of } \\
\text { wrongdoing }\end{array}$ & $\begin{array}{l}\text { Type of } \\
\text { wrongdoing; } \\
\text { reasons for not } \\
\text { whistle-blowing; } \\
\text { cost of } \\
\text { wrongdoing; } \\
\text { quality of evidence; } \\
\text { retaliation }\end{array}$ & $\begin{array}{l}\text { (1) Employees who observed perceived } \\
\text { wrongdoing involved mismanagement, sexual } \\
\text { harassment, or unspecified legal violations were } \\
\text { significantly more likely to report it than were } \\
\text { employees who observed stealing, waste, safety } \\
\text { problems, or discrimination; (2) type of } \\
\text { wrongdoing was significantly related to reasons } \\
\text { given by employees who observed wrongdoing } \\
\text { but did not report it, across all forms of } \\
\text { wrongdoing; and (3) type of wrongdoing was } \\
\text { significantly related to the cost of the } \\
\text { wrongdoing, the quality of the evidence about } \\
\text { the wrongdoing, and the comprehensiveness of } \\
\text { retaliation against the whistle-blower }\end{array}$ & $\begin{array}{l}\text { Data from } 3,288 \\
\text { employees, or about } \\
\text { thirty three percent of } \\
\text { those who were } \\
\text { contacted analyzed using } \\
\text { chi square analysis and } \\
\text { one-way ANOVAs }\end{array}$ \\
\hline $\begin{array}{l}\text { Park and } \\
\text { Blenkinsopp } \\
(2009)\end{array}$ & $\begin{array}{l}\text { Theory of } \\
\text { planned } \\
\text { behavior }\end{array}$ & $\begin{array}{l}\text { Attitude; subjective } \\
\text { norm; perceived } \\
\text { behavior control; } \\
\text { intention }\end{array}$ & $\begin{array}{l}\text { Attitude, subjective norm, and perceived } \\
\text { behavioral control had significantly positive } \\
\text { main effects on internal whistle-blowing } \\
\text { intentions, but for external whistle-blowing } \\
\text { intentions, only subjective norm was significant }\end{array}$ & $\begin{array}{l}296 \text { responses from } \\
\text { South Korea police } \\
\text { officers collected from } \\
\text { November } 2003 \text { and } \\
\text { May } 2004 \text { analyzed } \\
\text { using regression analysis }\end{array}$ \\
\hline $\begin{array}{l}\text { Peek, } \\
\text { Roxas, } \\
\text { Peek, } \\
\text { Robichaud, } \\
\text { Salazar, and } \\
\text { Codina } \\
(2007)\end{array}$ & $\begin{array}{l}\text { Cultural } \\
\text { dimensions; } \\
\text { NAFTA; } \\
\text { sexual } \\
\text { harassment }\end{array}$ & $\begin{array}{l}\text { Power distance; } \\
\text { individualism; } \\
\text { uncertainty } \\
\text { avoidance; } \\
\text { masculinity; } \\
\text { Mexico; U.S.; } \\
\text { Canada }\end{array}$ & $\begin{array}{l}\text { Significant differences in the intentions to blow } \\
\text { the whistle for students from the three countries; } \\
\text { however, the differences were not in the } \\
\text { expected direction }\end{array}$ & $\begin{array}{l}\text { Data from thirty-seven } \\
\text { U.S., twenty-four } \\
\text { Canadian, and seventeen } \\
\text { Mexican business } \\
\text { students from the three } \\
\text { NAFTS countries } \\
\text { collected using a } \\
\text { possible Sexual } \\
\text { Harassment scenario } \\
\text { from Arthur Andersen's } \\
\text { Business Ethics Program }\end{array}$ \\
\hline $\begin{array}{l}\text { Rothschild } \\
\text { and Miethe } \\
(1999)\end{array}$ & $\begin{array}{l}\text { Retaliation } \\
\text { against whistle- } \\
\text { blower }\end{array}$ & $\begin{array}{l}\text { Nonobservers; } \\
\text { silent observers; } \\
\text { internal and } \\
\text { external whistle- } \\
\text { blowers; private } \\
\text { and public } \\
\text { organizations; } \\
\text { nonprofit } \\
\text { organizational } \\
\text { characteristics; } \\
\text { retaliation }\end{array}$ & $\begin{array}{l}\text { (1) Whistle-blowing was more frequent in the } \\
\text { public sector than in the private; (2) there were } \\
\text { almost no sociodemographic characteristics that } \\
\text { distinguish the whistle-blower from silent } \\
\text { observer; and (3) whistle-blowers suffered } \\
\text { severe retaliation from management, especially } \\
\text { when their information proves significant }\end{array}$ & $\begin{array}{l}\text { National surveys aimed } \\
\text { at specific industries and } \\
\text { organizations followed } \\
\text { by telephonic interviews }\end{array}$ \\
\hline $\begin{array}{l}\text { Rothwell } \\
\text { and } \\
\text { Baldwin } \\
(2007)\end{array}$ & $\begin{array}{l}\text { Ethical Climate } \\
\text { Theory; code } \\
\text { of silence; } \\
\text { Georgia }\end{array}$ & $\begin{array}{l}\text { Ethical climate; } \\
\text { major and minor } \\
\text { violations; } \\
\text { misdemeanors; } \\
\text { felonies; vignettes; } \\
\text { tenure; size; } \\
\text { supervisory status }\end{array}$ & $\begin{array}{l}\text { (1) A friendship or team climate among police } \\
\text { officers in the state of Georgia explained } \\
\text { willingness to blow the whistle, but not the } \\
\text { actual frequency of blowing the whistle. (2) } \\
\text { Instead, supervisory status was the most } \\
\text { consistent predictor of both willingness to blow } \\
\text { the whistle and frequency of blowing the } \\
\text { whistle. Also, (3) the police were more inclined } \\
\text { than civilian employees to blow the whistle in } \\
\text { Georgia or put differently, they were less } \\
\text { inclined to maintain a code of silence }\end{array}$ & $\begin{array}{l}\text { Multiple regressions on } \\
\text { data obtained from } 198 \\
(69.5 \text { percent response } \\
\text { rate) police officers and } \\
184 \text { (66.9 percent } \\
\text { response rate) civilian } \\
\text { employees in Georgia }\end{array}$ \\
\hline
\end{tabular}




\begin{tabular}{|c|c|c|c|c|}
\hline Reference & Key concepts & Key variables & Key predictions and findings & Method and sample \\
\hline $\begin{array}{l}\text { Seifert } \\
(2006)\end{array}$ & $\begin{array}{l}\text { Organizational } \\
\text { justice; } \\
\text { perceived } \\
\text { likelihood of } \\
\text { whistle- } \\
\text { blowing }\end{array}$ & $\begin{array}{l}\text { Distributive justice; } \\
\text { procedural justice; } \\
\text { interactional } \\
\text { justice; internal vs } \\
\text { external whistle- } \\
\text { blowing; job role; } \\
\text { demographic } \\
\text { variables; OCBs }\end{array}$ & $\begin{array}{l}\text { The highest perceived likelihood of reporting } \\
\text { was posited and found when all whistle-blowing } \\
\text { circumstances were fair; and, the converse was } \\
\text { predicted and found when all whistle-blowing } \\
\text { circumstances were unfair. In mixed fairness } \\
\text { whistle-blowing situations, a higher perceived } \\
\text { likelihood of reporting was expected and found } \\
\text { when outcomes were fair versus when they were } \\
\text { not. A comparison of the responses of both } \\
\text { samples-management accountants and internal } \\
\text { auditors across the individual justice } \\
\text { circumstances revealed that the overall } \\
\text { perceived likelihood of reporting did not } \\
\text { significantly vary between internal auditors and } \\
\text { management accountants }\end{array}$ & $\begin{array}{l}\text { The sample included } \\
273 \text { internal auditors } \\
\text { who were members of } \\
\text { the Institute of Internal } \\
\text { Auditors (IIA) and } 244 \\
\text { management } \\
\text { accountants who were } \\
\text { members of the Institute } \\
\text { of Management } \\
\text { Accountants (IMA). A } \\
2 * 2 * 2 \text { factorial, quasi- } \\
\text { experimental, between- } \\
\text { subjects design with an } \\
\text { additional control case } \\
\text { for a total of nine case } \\
\text { was employed and the } \\
\text { data analyzed using } \\
\text { ANOVA }\end{array}$ \\
\hline $\begin{array}{l}\text { Sims and } \\
\text { Keenan } \\
(1998)\end{array}$ & $\begin{array}{l}\text { External } \\
\text { whistle- } \\
\text { blowing; } \\
\text { organizational } \\
\text { and } \\
\text { demographic } \\
\text { characteristics }\end{array}$ & $\begin{array}{l}\text { Supervisor support; } \\
\text { informal policies; } \\
\text { gender; ideal } \\
\text { values; } \\
\text { organizational } \\
\text { tenure; age; } \\
\text { education; } \\
\text { satisfaction; } \\
\text { commitment }\end{array}$ & $\begin{array}{l}\text { (1) External whistle-blowing was significantly } \\
\text { related to supervisor support, informal policies, } \\
\text { gender, and ideal values. (2) External whistle- } \\
\text { blowing was not significantly predicted by } \\
\text { formal policies, organizational tenure, age, } \\
\text { education, satisfaction, or commitment }\end{array}$ & \begin{tabular}{|l} 
Self-administered \\
questionnaire design was \\
used on a convenience \\
sample of 248 adult \\
students enrolled in a \\
college level \\
undergraduate and/or \\
graduate business. Data \\
were analyzed using \\
step-wise multiple \\
regression analysis \\
\end{tabular} \\
\hline $\begin{array}{l}\text { Singer, } \\
\text { Mitchell, } \\
\text { and Turner } \\
(1998)\end{array}$ & $\begin{array}{l}\text { Moral } \\
\text { intensity; } \\
\text { ethical } \\
\text { judgments; } \\
\text { need-for- } \\
\text { cognition }\end{array}$ & $\begin{array}{l}\text { Empathy; } \\
\text { proximity to } \\
\text { victims; employee } \\
\text { tenure; overall } \\
\text { ethicality }\end{array}$ & $\begin{array}{l}\text { (1) Study } 1 \text { showed that felt empathy for } \\
\text { potential victims predicted the likelihood of } \\
\text { whistle-blowing behavior, and that the } \\
\text { perceived overall ethicality of a wrongdoing } \\
\text { predicted felt empathy when potential victims } \\
\text { were psychologically and physically close; (2) } \\
\text { study } 2 \text { suggested a greater utilization of issue- } \\
\text { relevant information by high need-for-cognition } \\
\text { individuals in ethical decision making }\end{array}$ & $\begin{array}{l}\text { Scenario-based } \\
\text { questionnaires were } \\
\text { filled by fifty (thirty } \\
\text { female and twenty male) } \\
\text { employees at a large } \\
\text { international banking } \\
\text { firm based in } \\
\text { Christchurch }\end{array}$ \\
\hline $\begin{array}{l}\text { Somers and } \\
\text { Casal } \\
(1994)\end{array}$ & $\begin{array}{l}\text { Organizational } \\
\text { commitment }\end{array}$ & $\begin{array}{l}\text { Commitment; } \\
\text { intent to whistle- } \\
\text { blow }\end{array}$ & $\begin{array}{l}\text { The relationship between commitment and } \\
\text { intent to report wrongdoing had the form of an } \\
\text { inverted U, suggesting that moderate level of } \\
\text { commitment was most likely to result in } \\
\text { whistle-blowing }\end{array}$ & $\begin{array}{l}\text { Data from } 613 \\
\text { management } \\
\text { accountants who are } \\
\text { members of the National } \\
\text { Association of } \\
\text { Accountants (NAA) } \\
\text { analyzed using } \\
\text { regression analysis }\end{array}$ \\
\hline
\end{tabular}




\begin{tabular}{|c|c|c|c|c|}
\hline Reference & Key concepts & Key variables & Key predictions and findings & Method and sample \\
\hline $\begin{array}{l}\text { Stansbury } \\
\text { and Victor } \\
(2009)\end{array}$ & $\begin{array}{l}\text { Young } \\
\text { employees; } \\
\text { life-course } \\
\text { perspective }\end{array}$ & $\begin{array}{l}\text { Young and short- } \\
\text { tenured employees; } \\
\text { supervisor support; } \\
\text { coworker support; } \\
\text { newness to the } \\
\text { workforce }\end{array}$ & $\begin{array}{l}\text { (1) Young and short-tenured employees } \\
\text { perceived less informal prosocial control, and } \\
\text { (2) informal prosocial control boosted whistle- } \\
\text { blowing; however, (3) tests for mediation of the } \\
\text { relationship between youth and short-tenure and } \\
\text { whistle-blowing by informal social control } \\
\text { largely negative }\end{array}$ & $\begin{array}{l}\text { Data from the } 2003 \\
\text { NBES, designed and } \\
\text { conducted by the Ethics } \\
\text { Resources Center were } \\
\text { examined. } 1417 \text { replies } \\
\text { analyzed using } \\
\text { nonparametric tests and } \\
\text { logistic regression }\end{array}$ \\
\hline $\begin{array}{l}\text { Starkey } \\
\text { (1998) }\end{array}$ & \begin{tabular}{|l|} 
Dispositional \\
and situational \\
determinists of \\
whistle- \\
blowing
\end{tabular} & $\begin{array}{l}\text { Self-esteem, } \\
\text { interval vs external } \\
\text { orientation; ethical } \\
\text { beliefs; seriousness } \\
\text { of offense; } \\
\text { organizational } \\
\text { climate; power }\end{array}$ & $\begin{array}{l}\text { Whistle-blowing was strongly related to } \\
\text { situational variables with seriousness of the } \\
\text { offense and supportiveness of the organizational } \\
\text { climate being the strongest determinants }\end{array}$ & $\begin{array}{l}580 \text { self-report surveys } \\
\text { from four medium-sized } \\
\text { rural hospitals in } \\
\text { Mississippi and } \\
\text { Alabama }\end{array}$ \\
\hline $\begin{array}{l}\text { Treviño and } \\
\text { Victor } \\
(1992)\end{array}$ & $\begin{array}{l}\text { Peer reporting; } \\
\text { social context }\end{array}$ & $\begin{array}{l}\text { Group member } \\
\text { interests; liking; } \\
\text { evaluation; } \\
\text { negative emotional } \\
\text { reaction; role } \\
\text { responsibility }\end{array}$ & $\begin{array}{l}\text { This research hypothesized that two social } \\
\text { context conditions influenced group members' } \\
\text { evaluations of peer reporting of unethical } \\
\text { behavior and their own inclination to report } \\
\text { peers: (1) the misconduct threatened the } \\
\text { interests of group members and (2) peer } \\
\text { reporting was defined as a role responsibility of } \\
\text { group members. Mixed support for the } \\
\text { hypotheses was found }\end{array}$ & $\begin{array}{l}\text { Two scenario studies } \\
\text { adopted: Academic } \\
\text { cheating, and employee } \\
\text { theft in a fast-food } \\
\text { restaurant. } 2 * 2 \text { factorial } \\
\text { designs with scenarios } \\
\text { manipulating one factor } \\
\text { relating to the interests } \\
\text { of group members and a } \\
\text { second relating role } \\
\text { responsibility adopted. } \\
\text { Multivariate and } \\
\text { univariate analysis of } \\
\text { variance (MANOVA } \\
\text { and ANOVA) } \\
\text { procedures used along } \\
\text { with qualitative content } \\
\text { analysis techniques to } \\
\text { analyze responses to } \\
\text { optional open-ended } \\
\text { questions systematically }\end{array}$ \\
\hline $\begin{array}{l}\text { Victor, } \\
\text { Treviño, } \\
\text { and Shapiro } \\
\text { (1993) }\end{array}$ & $\begin{array}{l}\text { Peer reporting; } \\
\text { justice } \\
\text { evaluations; } \\
\text { social context } \\
\text { factors }\end{array}$ & $\begin{array}{l}\text { Role responsibility; } \\
\text { interests of group } \\
\text { members; } \\
\text { procedural, } \\
\text { distributive and } \\
\text { retributive justice }\end{array}$ & $\begin{array}{l}\text { (1) Inclination to report a peer for theft was } \\
\text { associated with role responsibility, the interests } \\
\text { of group members, and procedural justice } \\
\text { perceptions; (2) actual reporting behavior was } \\
\text { associated with the inclination to report and with } \\
\text { retributive justice evaluations }\end{array}$ & $\begin{array}{l}159 \text { surveys from } \\
\text { eighteen corporate- } \\
\text { owned fast food } \\
\text { restaurants analyzed } \\
\text { using multiple } \\
\text { regressions }\end{array}$ \\
\hline Wise (1995) & $\begin{array}{l}\text { Personal and } \\
\text { situational } \\
\text { variables }\end{array}$ & $\begin{array}{l}\text { Intrinsic religiosity; } \\
\text { internal locus of } \\
\text { control; high } \\
\text { general self- } \\
\text { efficacy; being } \\
\text { male; degree of } \\
\text { harm }\end{array}$ & $\begin{array}{l}\text { (1) Harm perceptions influenced whistle- } \\
\text { blowing intentions; (2) Females had } \\
\text { significantly higher intentions to blow the } \\
\text { whistle than males did }\end{array}$ & $\begin{array}{l}\text { Quasi-experimental } \\
\text { designed used with } \\
\text { students and the data } \\
\text { analyzed using } \\
\text { multivariate regressions, } \\
\text { MANOVA and a test of } \\
\text { correlation coefficients }\end{array}$ \\
\hline
\end{tabular}




\begin{tabular}{|l|l|l|l|l|}
\hline Reference & Key concepts & Key variables & Key predictions and findings & Method and sample \\
\hline $\begin{array}{l}\text { Zhang, } \\
\text { Chiu, and } \\
\text { Wei (2009) }\end{array}$ & $\begin{array}{l}\text { Internal } \\
\text { whistle- } \\
\text { blowing; China }\end{array}$ & $\begin{array}{l}\text { Positive affect; } \\
\text { organizational } \\
\text { ethical culture; } \\
\text { collective norms }\end{array}$ & $\begin{array}{l}\text { For would-be whistle-blowers, positive affect } \\
\text { and organizational ethical culture, by and large, } \\
\text { enhanced the expected efficacy of their whistle- } \\
\text { blowing intention by providing collective norms } \\
\text { concerning legitimate, management-sanctioned } \\
\text { behavior }\end{array}$ & $\begin{array}{l}\text { Questionnaire surveys } \\
\text { eollected from } 364 \\
\text { bankloyees in the ten } \\
\text { City, China and data } \\
\text { analyzed using zero- } \\
\text { order correlation, linear } \\
\text { regression, and } \\
\text { hierarchical moderated } \\
\text { regression analysis }\end{array}$ \\
\hline
\end{tabular}

